\title{
CREATING AN INSTRUMENT TO MEASURE PERCEPTIONS ABOUT ACCESS TO HEALTH-RELATED HIGHER EDUCATION PROGRAMMES IN SOUTH AFRICA
}

\author{
P. M. Orton* \\ International Education and Partnerships \\ e-mail: pennyo@dut.ac.za / https://orcid.org/0000-0001-7463-7889

\section{S. Essack ${ }^{* *}$} \\ Antimicrobial Research Unit \\ e-mail: essacks@ukzn.ac.za / https://orcid.org/0000-0003-3357-2761
}

\section{K. M. Nokes*}

Department of Nursing

e-mail: kathynokes@aol.com / https://orcid.org/0000-0001-9026-4189

\section{P. Brysiewicz ${ }^{* *}$}

School of Nursing and Public Health

e-mail: brysiewiczp@ukzn.ac.za / https://orcid.org/0000-0001-6258-1603

*Durban University of Technology

Durban, South Africa

**University of KwaZulu-Natal

Durban, South Africa

\section{ABSTRACT}

Background: The South African government has created countless policies that support the need to admit and graduate students who had been excluded from health-science programmes in higher education settings during the apartheid era.

Objective: to develop a questionnaire that could be used by various stakeholders to obtain their perceptions about access to health sciences education in higher education settings.

Method: A mixed methods design was used; the qualitative stage allowed for the identification of themes while the quantitative stage used measurement theory, to develop an instrument based on those themes.

Results: The overarching theme was Achieving equity of access for success is multi-factorial and has diverse and complex challenges and eight sub-themes emerged which were used to create a 17 -item questionnaire that has good content validity and reliability (Cronbach alpha $=.767$ ).

Conclusion: Further psychometric testing with larger, more diverse samples will result in a refined 
instrument that can be administered to various stakeholder groups, such as current and potential health sciences students and faculties, and used in programme evaluation. Health science programmes can use the instrument to measure access within different disciplines and possible changes over time as innovations are piloted. Different health sciences programmes can be compared and contrasted and objective data can be used to make systematic organizational changes.

Keywords: access, higher education, health sciences, instrument

\section{INTRODUCTION}

Education has been a critical initiative, in South Africa, towards uplifting people who were denied educational opportunities prior to democracy in 1994. The first democratically elected government in South Africa developed policies that embodied a vision of judicious access, a reasonable chance of success to all citizens who want to accomplish their capability through higher education, eradication of any unfair discrimination, and rectifying past inequalities. Implementing these policies has been difficult and progress slow, with government agencies continuing to reinforce the transformation agenda in higher education and address disparities in access with respect to socio-economic status, race, gender, geographical location, age, disability and HIV status (South Africa 2013, 1-2). Achieving sustained implementation of these changes is not unique to South Africa, with long-standing challenges related to access, equity, and inclusion remaining embedded in the United States of America (USA) (Golom 2018, 11).

As the international community works towards the Sustainable Development Goals, higher education (HE) is more critical than ever (Power, Millington and Bengtsson 2015, 6). South Africa needs to educate health care professionals who are accessible, affordable, appropriate and acceptable to the communities that they serve. Ideally, many graduates will return to work in the communities from which they come, which, in the South African context, refers to students from low socio-economic groups and rural areas, these often interwoven in South Africa (Orton 2015). Student success in regulation time refers to the throughput rates of universities within a specified time and is considered a measure of the effectiveness and efficiency of the higher education system (CHE 2013, 42). The requirement to finish in regulation time, results in admission policies which consider students ability to complete timeously as a selection criterion, requiring decent school leaving results to gain admission to health sciences programmes.

School leaving grades are reliable predictors of achievement in the first year of university, although in the South African milieu this may be unclear because of the manipulation of the marks in the National Senior Certificate (NSC) (Monyooe, Tjatji and Mosese 2014; Mouton, Louw and Strydom 2013). The four-year Health Sciences degrees, except for medicine and 
dentistry, had a graduation rate of 36 per cent in regulation time (CHE 2013, 47). This is a slight improvement on the national average recorded for the three-year degrees (29\%). This may be a result of the above average academic requirements students need in order to be chosen for health science programmes (CHE 2013, 47-48).

\section{REVIEW OF THE LITERATURE}

There are a number of predictors of participation in higher education, ranging from parental education level, secondary school achievement, socio-economic status, geography and ruralorigin (Connor et al. 2001; Marks et al. 2000), with the two chief obstacles being university fees and admission examinations (McCowan 2016, 2). A review of the Australian higher education system found under representation of indigenous people, those from remote areas and those in low socio-economic groups. They suggested that no awareness of the long-term benefits of higher education, and therefore no aspiration to participate in higher education and previous educational achievement were contributory factors. Those who did access higher education, needed greater levels of academic and financial support in order to achieve success. These factors are not confined to Australia but reflect those faced by people all over the world (Commonwealth of Australia 2008, 27-45).

Globally, social class is the most consistent predictor of participation in higher education (Deller and Oldford 2011; James 2007, 2-5; Archer et al. 2003; Connor et al. 2001). Higher education systems in many European countries are characterised by socio-economic class inequalities (Riddell and Weedon 2014, 27). Socio-economic status has been a feature of the German higher education system which is class-based and segregated, with a highly stratified secondary schooling system. This results in citizens from lower socio-economic classes being nine times less likely to access higher education compared with applicants from an upper socioeconomic background (Powell and Solga 2011; James 2007). Portugal reflects a similar pattern of access with students from the highest socio-economic group ten times more likely to be admitted to higher education than citizens in the lowest (James 2007).

The English higher education system has considerable social imbalances (Higher Education Funding Council for England (HEFCE) 2013). Half the English population is classified as having low socio-economic status, but only 28 per cent of the young, full-time entrants to first degree courses represent this group (James 2007; Corver 2005, 267).

Those who come from more well-off areas are five to six times more likely to access university education than those from working class areas (James 2007). In an effort to widen participation the government adopted a large-scale equity programme by providing funding incentives to universities, removing upfront fees, and encouraging part-time attendance 
(Department of Business, Innovation and Skills 2012; James 2007). However, the current government has had to implement economic austerity measures, as has been seen throughout the Western world, and has reduced the amount of government funding allocated to higher education (HEFCE 2013). Ireland has seen a significant increase in participation of students of lower socio-economic status, in higher education, with a total participation rate of 60 per cent (Keane 2011). Students from the managerial and professional classes are also taking advantage of Britain's expanded higher education system in Ireland (Higher Education Authority 2008; James 2007).

It is more common for young people whose parents have higher education qualifications to participate in higher education (Powell and Solga 2011). Even in a country like Finland, who has an egalitarian public-school system, participation in higher education is deeply skewed according to parental educational background (James 2007). This pattern of access and participation is common throughout the Scandinavian countries with Finland reporting these young people are seven times more likely to go to university than someone from a family with less educated parents (James 2007). Norway reports that students whose parents had higher education were nine times as likely to attend university in 1999 and four times as likely in 2011 (Hovdhaugen 2013). This report indicates that this is changing, with increasing numbers of students accessing higher education whose parents did not (Hovdhaugen 2013).

In the USA, people of a lower socio-economic status are accessing higher education less than before due to normalised entrance tests and high tuition charges (Layer 2005). Despite interventions in the USA such as financial aid, affirmative action and outreach programmes (Wolfenden 2013), there is some support for growing inequality between the classes in accessing higher education, as suggested by Astin and Oseguera (2004), specifically regarding who can attend the most sought after colleges and universities. Several programmes have concentrated on the participation of minority groups and were legislated in order to address the legacy of racial discrimination (Garces 2012).

In 2001, the Brazilian government introduced a quota system for non-white Brazilian students in higher education, in response to the inequalities found in the Brazilian higher education system. The Brazilian higher education milieu is populated by those from the affluent classes. University admission was almost exclusively based on an entrance examination. Those students from private schools are far better prepared for these examinations than those from public schools, which results in a dominance of wealthy students at the public universities, which are commonly free (Telles and Paixao 2013). The students from underprivileged socioeconomic backgrounds, who managed to qualify for university admission, often ended up attending private universities, which they had to raise the funds to pay for. Brazil introduced 
over a period of four (4) years a quota system that required all public universities to earmark 50 per cent of places for students who attended public schools, have low family income or are of indigenous, Black or Brown race (Telles and Paixao 2013), all proxies of socio-economic disadvantage in Brazil. This law of quotas was not without criticism, detractors arguing that Brazil has never had policy along racial lines, that initiating quotas will lead to a dropping of standards in Brazilian universities, and that the government should rather pay attention to improving basic education so that all people can participate on an equal footing (Telles and Paixao 2013). However, those advocating for the law, such as the Rector of the University of Rio de Janeiro, Professor Ricardo Vieralves, report a positive experience with these students, as they work harder, generally graduate in a shorter time and drop out less often. While they admit that initially these student's marks are not as good as the private school scholars they quickly catch up and often do better than those who accessed the institution on merit (Telles and Paixao 2013).

Until 1997, entry to Chinese universities was merit based and linked to college entrance examinations, after which the user pay principle was adopted, with financial circumstances being added to the selection criteria (Wang 2011). Many low- and middle-income families could not afford to send their children to university, as university fees are primarily sourced from the family (Wang 2011). As in most other countries in the world, socio-economic status is regarded as having an influence on Chinese student's success in the Gaokao selection tests. However, in Eastern China, socio-economic status does not emerge as affecting performance as much as socio demographic factors (Lui 2013).

Throughout the world, inequalities in access to higher education, are often as a result of geography, where people are born or where they live. In China, higher education opportunities are better in urban than in the rural areas (Jacob 2006; Wang 2011), making opportunities more readily available to those living in metropolitan areas (Jacob 2006). Access to higher education, for potential students from rural areas, is difficult due to issues such as socio-economic status, distance from family support and the lack of financial resources (Jacob 2006). Language is another impediment to higher education in China for minority groups (Jacob 2006), who learn Mandarin at school and are often not fluent enough to access higher education, where Mandarin is the language of instruction (Jacob 2006). As universities move towards technology mediated education, such as on-line courses, these geographic barriers may lessen.

Ensuring equitable access to higher education and specifically health sciences higher education programmes is a multi-facetted, global concern that has an additional layer of complexity in South Africa, due to its colonial and apartheid past (Orton 2015). Transformation of the healthcare system to better meet the needs of the South Africa's population could be 
facilitated through the employment of graduates from programmes of higher education in health sciences. According to Statistics South Africa, 80 per cent of the South African population are African; 9 per cent Coloured; 8 per cent are White and 3 per cent Asian/Indian (Statistics South Africa 2017). This racial distribution is not reflected in the demographics of students in health sciences programmes in higher education institution. According to the 2016 data, 40 per cent of the students enrolled in these programmes are African, with females comprising the greatest numbers $(70.05 \%)$, which is to be expected in light of the traditional gender composition of many health professions, such as nursing. There is an under representation of African, particularly male students in health sciences programmes. While medical students are racially diverse, specifically with 39 per cent being African; 33 per cent White; 14 per cent Indian/Asian; 13 per cent Coloured; and 1 per cent not being in any of those groups, these numbers do not reflect the South African population (Van der Merwe, Van Zyl, St Clair Gibson et al. 2016).

Eight South African universities offer health science degrees, including medicine, with the South African National Department of Health identifying Nursing, Pharmacy and Medicine as scarce skills in the public health sector (Guri-Rosenbilt, Sebkova and Teichler 2007). This research used a sequential, exploratory mixed methods approach to explore perceptions of academic leaders in health science programmes about how South African government policies regarding access and transformation of higher education were being implemented in the context of health science education. The goal was to identify the complexity involved in access in order to develop a questionnaire that could be used by different stakeholders for evaluation and benchmarking purposes.

\section{METHOD}

The study used a sequential, exploratory mixed methods approach, with the qualitative stage preceding the quantitative methods of data collection and analysis (Johnson and Onwuegbuzie 2004; Tashakkori and Teddlie 2003). The qualitative stage allowed for the identification of themes and sub-themes about access to higher education in health programmes from the perspectives of academic leaders, while the quantitative stage used measurement theory to develop an instrument based on the sub-themes identified during the qualitative stage. Ethical clearance was obtained from the University of KwaZulu-Natal's Biomedical Research Ethics Committee (HSS/1276/010D).

\section{Stage 1: Qualitative: Identifying themes about access}

Within the homogeneous tradition (Onwuegbuzie and Leech 2007), four representative South 
African universities were purposefully sampled, and the Deans of Health Science faculties interviewed. The Faculty of Health Sciences Deans are responsible for recruiting and enrolling students into the various schools and/or departments, as well as meeting enrolment targets, and developing and implementing access policies. The six participants consisted of two Deans and three Deputy Deans of Health Science, and a Senior Administrator in a College of Health Sciences $(\mathrm{N}=6)$. All the demographic data were self-reported and participants all had a doctoral qualification, with four being female and two being male.

\section{DATA COLLECTION}

The guide questions (Table 1) were derived from a review of documents that dealt with access to higher education in South Africa and human resources for health, which were sourced off the internet, the sampled university websites, and the websites of the South African Department of Health and Department of Higher Education and Training. The interviews started with a grand tour question,

"I trust you are aware of the governments` White Paper on the Transformation of Higher Education that came out in 1997? One principle of this white paper was redress for past inequities. The universities, as autonomous institutions, have translated parts of that white paper into selection and admission policies. I am interested to hear of your knowledge and experience of how the implementation of these policies is affecting access to health science education."

and was followed by eleven probing questions. These in depth semi-structured individual interviews lasted between 30 and 40 minutes, were voice recorded, and transcribed verbatim.

Table 1. Interview questions: Stage 1 Probes following the grand tour question

\begin{tabular}{|l|}
\hline What do you think has facilitated access to health science education at your university? \\
\hline What do you think the challenges, if any, are to accessing health science education in your university? \\
\hline $\begin{array}{l}\text { Please describe the student demographic profile at this university as you experience it. } \\
\text { Do you think it is representative of the country demographic in terms of class, race and gender? Explain. }\end{array}$ \\
\hline $\begin{array}{l}\text { Are you aware of the student profile in terms of secondary schooling and/or where the students originally come } \\
\text { from/live? }\end{array}$ \\
\hline Are you seeing an increase in students from rural areas? \\
\hline What are the barriers, do you think, to students from rural areas accessing health science education in universities? \\
\hline $\begin{array}{l}\text { It has been said that students from rural areas will most often go back to these areas on graduation, which is what } \\
\text { this country needs. How do you think the university might attract more students from these areas? }\end{array}$ \\
\hline $\begin{array}{l}\text { What do you think would make health science education at university an attractive option for students from rural } \\
\text { areas? }\end{array}$ \\
\hline $\begin{array}{l}\text { How have the access policies, particularly alternative access, affected student retention and throughput? Why do } \\
\text { you think this is happening? }\end{array}$ \\
\hline What has facilitated student retention and throughput? \\
\hline What, do you think, are the challenges related to student retention and throughput? \\
\hline
\end{tabular}

\section{Data analysis}

An inductive thematic analysis method was used to search across the data set to find repeated 
patterns of meaning (Braun and Clarke 2006, 77-101). The data set used a constructionist perspective, where the emergent themes were organized around conditions applicable to access to higher education. The six phases of thematic analysis were followed; one researcher conducted the interviews and transcribed them verbatim enabling immersion in the data. The transcripts were read and re-read to identify the meaning in the words of participants, and the researcher jotted down thoughts and ideas related to the data that highlighted important ideas in the data. The interviews were read from the perspective of transformation of access to higher education for health sciences, with important or interesting aspects being highlighted and probed in subsequent interviews. Ideas were generated from meaningful units of data that were abstracted into codes, written on a flip chart and added to as new codes were identified. These codes were condensed into eight sub-themes that were refined and condensed into an overarching theme.

\section{RESULTS OF THEMATIC ANALYSIS}

The overarching theme was Achieving equity of access for successful transformation is multifactorial and has diverse and complex challenges, with an additional eight sub-themes being identified.

\section{Sub-theme 1: Promotion of the health science disciplines}

There was consensus among participants that some of the health science professions, except perhaps nursing, medicine and perhaps physiotherapy, are not well known, particularly to rural learners who have few opportunities for exposure to the variety of health science disciplines, "which I think is our downfall, it is of course even worse in the rural areas ... you are not even exposed to somebody doing something interesting that you don't even have a name for ...". Participants indicated a need for targeted marketing strategies “... we have to do quite a lot more, in advertising our profession ... look at websites and put on video inserts, stuff that they can really see what it is all about". The use of visual media was considered important "we are making an integrated video where we are starting with a success story in the community, and bring it back to where it started"

\section{Sub-theme 2: Reasons for choosing a health science profession}

Participants thought that students may select the health profession for reasons other than a passion to help sick people, possibly because they think they will be "rich" one day, have elevated status in the community or because their family want them to do it, "it is good to have a doctor in the house!" However, these motives are often not enough to keep students 
determined to succeed in a demanding academic programme, which in turn impacts university throughput rate. Participants shared that many economically underprivileged students chose a health science profession based on extraneous factors, such as accommodation and housing. Family tradition is a factor often referred to in the choice of a health sciences profession, with one participant reporting that a third of those who completed their degree did not practice medicine, having been pushed in that direction by family.

\section{Sub-theme 3: Competitiveness}

Most of the health sciences programmes are oversubscribed "... with the competition in health sciences ... it is just this tremendous over supply, we can fill all our positions ten times ...”. Policies compel the admission of applicants from previously disadvantaged groups but in reality the students do not come from quintile 1 and 2 schools: “... the vast majority ... come from Model C schools and private schools".

\section{Sub-theme 4: Health sciences programmes use different criteria}

Students are selected on predetermined criteria and, because the demand exceeds available spaces, top students are generally chosen. Universities had different quota criteria, with two having racial quotas representative of the country`s demographic profile and a small allocation for Southern African Development Community students. One university had language quotas and did not consider race, and another had started to allocate places to rural students. None of the universities used socio-economic status when considering applicants for admission and all used race as a proxy for disadvantage. “... we went through this year`s exercise using the normal quota system ....... in terms of $69 \%$ for Blacks sounds like a noble gesture, but when you look at this list we started realizing that we are not really covering rural ...”. Another said "... all previously disadvantaged candidates meeting the minimum admissions criteria will be taken in, whereas all the others would be based on merit". Normalized examinations, such as the National Benchmark Tests, set the entrance criteria for some institutions, while others used matriculation results and interviews to identify qualifying students.

\section{Sub-theme 5: Challenges to transformation}

Two challenges affecting access for transformation of health sciences education were poverty and poor schooling. One participant shared: "another challenge is funding, those students come from very poor families and we would have loved that all students get a bursary, but it is not possible". Another said that on many occasions, students were accepted but asked to defer admission while they sought funds. There was general consensus that poor schooling ill- 
prepared students, specifically those from rural areas, "... the language, because they are rural from very poor schools, some of the students cannot express themselves in English, they are poor in physical science, they are poor in ... maths ...".

\section{Sub-theme 6: Alternative access}

Most Faculties of Health Sciences offered some means of alternative access to advance redress, with extended curricula and foundation programmes being two strategies. One described their foundation programme as a bridging year for those who do not meet the academic requirements, during which they study "sociology, psychology, computer literacy and other relevant modules". Another indicated that they have science foundation programmes for students with poor marks. Despite an over-all feeling that these students did not perform as well as mainstream students, some interviewees said their experience was contrary: “... what we find is students come in from the BSc programme who were not initially selected, they do better, they get into natural sciences, they prepare a year and then we select ...". Another had a positive experience of students in alternative access programmes, “... the average percentage of those students being higher than of those who came through the normal route".

\section{Sub-theme 7: Innovation in teaching and learning}

Certain participants suggested that the curriculum design appealed to prospective students, while others disagreed, contending that while academics might think that, they challenged anyone to find a student who agreed. Mention was made of "common teaching platforms", where an interprofessional approach was adopted that might attract potential students to health sciences. One shared: "We are doing interdisciplinary training with family medicine and just being exposed at the clinics and various platforms gets interest ...". Another suggested that they have "outside teaching platforms, not only at the university, but at district hospitals".

\section{Sub-theme 8: Retention and throughput rates}

Participants identified student support, completion in minimum time and dropout rates as impacting retention and throughput rates. A variety of support measures were adopted across Faculties of Health Sciences, with the most prevalent being mentorship of first and second years by seniors, as well as group support structures and learning contracts. Most felt that completion in minimum time was a problem due to the "type" of students being admitted who need extra time and support, and some thought it was unfair in the context of inadequately prepared students, as extended learning programmes required students to be at university for a year longer than the minimum. The funding model that rewards achievement in minimum time may 
be at cross purposes with transformation and rectifying equity, as each teaching input grant depends on one full-time student graduating, this money being important to sustaining the programme. Retention rates are one of the parameters of efficiency that has become a focus of the South African Department of Higher Education and Training, as well as the universities. One participant shared that students usually "screen" themselves in the first two years, during which time they drop out, which makes throughput good during the remaining years. Socioeconomic factors also affect drop-out rates "if you've got these kinds of non-academic burdens on your shoulders it does impact on your studies".

\section{Stage 2: Quantitative: Development of a valid and reliable tool to measure perceptions of access to health sciences higher education}

Measurement theory was used to develop the instrument (Streiner and Norman 1995; De Vellis 2012). The first step in instrument development is to clearly determine what we wanted to measure which was perceptions of access to health sciences higher education. The second step is to generate an item pool and we did that by writing three items for each of the eight subthemes that had emerged during the qualitative phase. The third step is to determine the format for measurement and we used a 5-point Likert type scale to measure perceptions. The fourth step is to have an initial item pool reviewed by experts which was achieved over three rounds.

\section{SETTING/SAMPLE}

Participants in the fourth step were purposively sampled among the academic and administrative staff responsible for access at all eight public universities offering health science education who were attending a South African Committee of Health Science Deans conference. In order to calculate an Index of Content Validity (I-CVI) for each of the 24 items, participants rated the overall instructions and each item for relevance and clarity of wording using a 4-point scale. Written informed consent was given, with 20 instruments being distributed and 11 completed (six by participants in a teaching role, four were heads of health science schools, departments or programmes, and one a Dean of Health Sciences). For each item, the I-CVI was calculated as the number of experts who gave a rating of 3 (quite relevant) or 4 (highly relevant), with an I-CVI of 0.80 being judged acceptable (Streiner and Norman 1995; De Vellis 2012). Three items were identified as requiring clarification and no items were discarded in this round, with one item being added, resulting in a 25 -item instrument. The instrument was scored for readability, with the FLESCH Reading Ease score being 41.2 and the FLESCH-Kincaid grade level being 11.2. This suggested that the instrument was fairly easy to read and understood by anyone with a Grade 11 education. 
The 25-item questionnaire was distributed via e mail using SurveyMonkey ${ }^{\text {TM }}$ to 25 Deans and Deputy Deans of Health Sciences at the eight universities offering health sciences. Reminders were sent on two occasions with 16 questionnaires (64\%) being returned. The questionnaire provided five ranked responses for each of the 25 items using an ordinal Likert Scale: $1=$ very important to $5=$ unimportant.

Table 2: Perceptions about access to health-related higher education in South Africa instrument

\begin{tabular}{|c|c|c|c|c|c|c|}
\hline Sub-theme & Item & 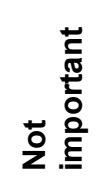 & 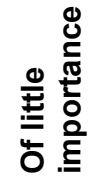 & 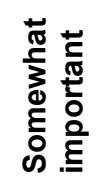 & 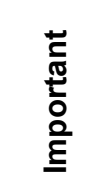 & 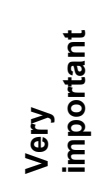 \\
\hline \multirow{2}{*}{$\begin{array}{l}\text { 1. Promotion of } \\
\text { the health } \\
\text { science } \\
\text { disciplines }\end{array}$} & $\begin{array}{l}\text { 1. Different professions within healthcare, such as } \\
\text { nursing, physiotherapy and medicine, are marketed } \\
\text { equally }\end{array}$ & 0 & 0 & $\begin{array}{c}1 \\
(4 \%)\end{array}$ & $\begin{array}{c}9 \\
(39 \%)\end{array}$ & $\begin{array}{c}13 \\
(57 \%)\end{array}$ \\
\hline & $\begin{array}{l}\text { 2. Current marketing strategies use all available media, } \\
\text { including print, electronic and social media. }\end{array}$ & 0 & 0 & $\begin{array}{c}1 \\
(4 \%) \\
\end{array}$ & $\begin{array}{c}7 \\
(30 \%) \\
\end{array}$ & $\begin{array}{c}15 \\
(65 \%)\end{array}$ \\
\hline \multirow{2}{*}{$\begin{array}{l}\text { 2. Reason for } \\
\text { choosing a } \\
\text { health } \\
\text { science } \\
\text { discipline } \\
\end{array}$} & $\begin{array}{l}\text { 3. Potential students are well informed when they make } \\
\text { their choice of the health sciences profession }\end{array}$ & 0 & 0 & $\begin{array}{c}1 \\
(4 \%)\end{array}$ & $\begin{array}{c}3 \\
(13 \%)\end{array}$ & $\begin{array}{c}19 \\
(83 \%)\end{array}$ \\
\hline & $\begin{array}{l}\text { 4. Housing/student accommodation is a major motivating } \\
\text { factor when students choose health science } \\
\text { programmes }\end{array}$ & 0 & $\begin{array}{c}3 \\
(13 \%)\end{array}$ & $\begin{array}{c}5 \\
(22 \%)\end{array}$ & $\begin{array}{c}9 \\
(39 \%)\end{array}$ & $\begin{array}{c}5 \\
(22 \%)\end{array}$ \\
\hline \multirow[t]{2}{*}{$\begin{array}{l}\text { 3. Competitive- } \\
\text { ness }\end{array}$} & $\begin{array}{l}\text { 5. There are adequate numbers of students coming from } \\
\text { rural areas }\end{array}$ & 0 & $\begin{array}{c}3 \\
(13 \%) \\
\end{array}$ & $\begin{array}{c}2 \\
(9 \%) \\
\end{array}$ & $\begin{array}{c}9 \\
(39 \%)\end{array}$ & $\begin{array}{c}9 \\
(39 \%) \\
\end{array}$ \\
\hline & $\begin{array}{l}\text { 6. Many students take easier matric subjects just to } \\
\text { strengthen their application for admission }\end{array}$ & $\begin{array}{c}4 \\
(17 \%)\end{array}$ & $\begin{array}{c}2 \\
(9 \%) \\
\end{array}$ & $\begin{array}{c}9 \\
(39 \%)\end{array}$ & $\begin{array}{c}4 \\
(17 \%)\end{array}$ & $\begin{array}{c}4 \\
(17 \%)\end{array}$ \\
\hline \multirow{3}{*}{$\begin{array}{l}\text { 4. Health } \\
\text { sciences } \\
\text { programmes } \\
\text { use different } \\
\text { criteria }\end{array}$} & $\begin{array}{l}\text { 7. Some students receive priority admission status based } \\
\text { on a history of being disadvantaged }\end{array}$ & $\begin{array}{c}5 \\
(22 \%) \\
\end{array}$ & $\begin{array}{c}1 \\
(4 \%) \\
\end{array}$ & $\begin{array}{c}2 \\
(9 \%)\end{array}$ & $\begin{array}{c}12 \\
(52 \%)\end{array}$ & $\begin{array}{c}3 \\
(13 \%) \\
\end{array}$ \\
\hline & $\begin{array}{l}\text { 8. Results from standardized exams such as NBT's are a } \\
\text { factor in determining whether a student is admitted }\end{array}$ & $\begin{array}{c}1 \\
(4 \%)\end{array}$ & $\begin{array}{c}2 \\
(9 \%)\end{array}$ & $\begin{array}{c}6 \\
(26 \%)\end{array}$ & $\begin{array}{c}13 \\
(57 \%)\end{array}$ & $\begin{array}{c}1 \\
(4 \%)\end{array}$ \\
\hline & $\begin{array}{l}\text { 9. The school/discipline/department sets the "bar" for } \\
\text { admission and students who don "t meet these minimum } \\
\text { criteria are not admitted }\end{array}$ & 0 & 0 & $\begin{array}{c}5 \\
(22 \%)\end{array}$ & $\begin{array}{c}8 \\
(35 \%)\end{array}$ & $\begin{array}{c}10 \\
(44 \%)\end{array}$ \\
\hline \multirow[t]{2}{*}{$\begin{array}{l}\text { 5. Challenges to } \\
\text { transformation }\end{array}$} & $\begin{array}{l}\text { 10. Economic constraints do not impact on whether a } \\
\text { qualified student is admitted }\end{array}$ & 0 & $\begin{array}{c}1 \\
(4 \%)\end{array}$ & $\begin{array}{c}3 \\
(13 \%)\end{array}$ & $\begin{array}{c}9 \\
(39 \%)\end{array}$ & $\begin{array}{c}9 \\
(39 \%)\end{array}$ \\
\hline & $\begin{array}{l}\text { 11. Students whose home language is not English are } \\
\text { adequately prepared for university study }\end{array}$ & 0 & $\begin{array}{c}3 \\
(13 \%)\end{array}$ & $\begin{array}{c}2 \\
(9 \%)\end{array}$ & $\begin{array}{c}9 \\
(39 \%)\end{array}$ & $\begin{array}{c}7 \\
(30 \%) \\
\end{array}$ \\
\hline \multirow[t]{3}{*}{$\begin{array}{l}\text { 6. Alternative } \\
\text { access }\end{array}$} & $\begin{array}{l}\text { 12. Students who are not prepared for health sciences } \\
\text { university study can take foundation courses to better } \\
\text { equip them for academic success }\end{array}$ & 0 & $\begin{array}{c}2 \\
(9 \%)\end{array}$ & $\begin{array}{c}4 \\
(17 \%)\end{array}$ & $\begin{array}{c}10 \\
(44 \%)\end{array}$ & $\begin{array}{c}6 \\
(26 \%)\end{array}$ \\
\hline & $\begin{array}{l}\text { 13. Students are given the opportunity to take longer than } \\
\text { the usual number of years of study in order to be } \\
\text { successful }\end{array}$ & 0 & $\begin{array}{c}4 \\
(17 \%)\end{array}$ & $\begin{array}{c}6 \\
(26 \%)\end{array}$ & $\begin{array}{c}10 \\
(44 \%)\end{array}$ & $\begin{array}{c}3 \\
(13 \%)\end{array}$ \\
\hline & $\begin{array}{l}\text { 14. Students who complete alternative access programmes } \\
\text { perform equally well to mainstream students }\end{array}$ & $\begin{array}{c}3 \\
(13 \%)\end{array}$ & $\begin{array}{c}2 \\
(9 \%)\end{array}$ & $\begin{array}{c}7 \\
(30 \%)\end{array}$ & $\begin{array}{c}10 \\
(44 \%)\end{array}$ & $\begin{array}{c}1 \\
(4 \%)\end{array}$ \\
\hline $\begin{array}{l}\text { 7. Innovation in } \\
\text { teaching \& } \\
\text { learning }\end{array}$ & 15. Learner focused curricula improve student success & $\begin{array}{c}1 \\
(4 \%)\end{array}$ & 0 & $\begin{array}{c}3 \\
(13 \%)\end{array}$ & $\begin{array}{c}8 \\
(35 \%)\end{array}$ & $\begin{array}{c}11 \\
(48 \%)\end{array}$ \\
\hline \multirow{2}{*}{$\begin{array}{l}\text { 8. Retention \& } \\
\text { throughput } \\
\text { rates }\end{array}$} & $\begin{array}{l}\text { 16. Early identification and intervention for at-risk students } \\
\text { improves retention }\end{array}$ & 0 & 0 & 0 & $\begin{array}{c}7 \\
(30 \%) \\
\end{array}$ & $\begin{array}{c}16 \\
(70 \%)\end{array}$ \\
\hline & $\begin{array}{l}\text { 17. Many at-risk students drop out early in their programme } \\
\text { of study }\end{array}$ & 0 & $\begin{array}{c}1 \\
(4 \%)\end{array}$ & $\begin{array}{c}4 \\
(17 \%)\end{array}$ & $\begin{array}{c}10 \\
(44 \%)\end{array}$ & $\begin{array}{c}7 \\
(30 \%)\end{array}$ \\
\hline
\end{tabular}

Based on feedback from these participants, the 25 -item questionnaire was sent out for a third and final time, using Survey Monkey, to 87 administrative staff at the eight universities offering health sciences. These administrators ranged from Registrars, Deans of Students, Admissions 
Officers, Recruitment Officers, Financial Aid Officers and other staff who are responsible for access to university. Five were returned as undeliverable as the recipient had left the university, with the final sample being 82 . The request for participation was sent three times at intervals of 10 days, and a 9.75 per cent $(n=8)$ response rate was achieved and were used for analysis. Four questions were rated by three of the respondents as unimportant and a number were rated as not clear. Based on these results, we considered reducing the instrument from 25 to 12 items. Using the 0.80 criteria for the Index of Content Validity, 13 items would have been discarded, however this would have resulted in eliminating all the items from sub-themes 1, 3, and 7 that had been identified during the qualitative stage.

The fifth step of instrument development is to consider the inclusion of the validation items. In order to base the instrument on the qualitative data and the small sample size from the last validation round, we decided to retain at least one item from each of the 8 sub-themes. Two items scored 69 per cent and were retained for Sub-theme 1; two items scored 77 per cent for Sub-theme 3 and were both retained; and one item scored the highest for Sub-theme 7 and was retained, which resulted in a 17-item scale. The total mean score on the 17-item instrument was 63.66 (SD 6.92) and the total Cronbach Alpha was computed as .767 (Table 2)

\section{DISCUSSION}

Organizational rather than individual level changes are needed to create sustainable environments that support access by previously marginalized populations (Golom 2018, 13). Access to health sciences education in South Africa universities is steeped in both political and technical processes, the political will and capacity, as well as the expertise in educational policies (Orton 2015). Affordability and sustainability constraints make this more difficult in a developing country like South Africa, which is a relatively young democracy. Health sciences graduates can lead this transformation, and leaders need to include those who have not had the opportunity but who are well placed to contribute to the vision for improved access to universal health care and improved health outcomes (National Department of Health 2012).

The instrument developed through this mixed methods research could be used to provide objective evidence about the perceptions of various university stakeholders on access to healthrelated higher education. Health science programmes can use the instrument to establish the perceptions regarding transformation changes in access within the same university, and to monitor changes over time as innovations are piloted. The various health sciences programmes can be compared and contrasted, and objective data used to make systematic change. Transforming health sciences education in universities needs to include targeted innovations based on objective evidence in order to evaluate the impact of the changes. The instrument 
developed through this mixed methods research reflects the opinions of a range of key stakeholders and material identified in the literature. Further testing will add the insights of the targeted population, those who were disadvantaged in their ability to enter health education programmes in higher education.

\section{LIMITATIONS}

We focused on access to higher education for health sciences and sought the perceptions of faculties in all eight Faculties in South Africa preparing these students. There could be entirely different perception from faculties in a different type of programme such as engineering. Future work could take the final instrument and assess perceptions of faculties in different educational tracks.

\section{CONCLUSION}

Access to higher education for health sciences is impacted by student-related factors such as home geographic location and school related factors both in the preparatory programmes and within the higher education setting. To further establish the validity of the instrument, we plan to continue with the sixth step of instrument development which is to administer the items to a development sample which would include faculties of health sciences, current students in health sciences, and applicants to health sciences programmes. Larger samples will support further psychometric testing including factor analysis. A validated instrument could be used in programme evaluation both within one university to explore perceptions of access within different departments and to compare similar programmes across different universities. The components within the instrument could also be shared with career counsellors of students interested in health-related higher education to help students to focus their admission efforts productively.

\section{REFERENCES}

Archer, L., M. Hutchings, A. Ross, C. Leathwood, R. Gilchrist and D. Phillips. 2003. Higher education and social class. Issues of exclusion and inclusion. London: Routledge Falmer.

Astin, A. W. and L. Oseguera. 2004. The declining "equity" of American higher education. Review of Higher Education 27: 321-341.

Braun, V. and V. Clarke. 2006. Using thematic analysis in psychology. Qualitative Research in Psychology 3(2): 77-101.

CHE see Council on Higher Education.

Commonwealth of Australia. 2008. Review of Australian Higher Education. Canberra: Australian Government.

Connor, H., S. Dewson, C. Tyers, J. Eccles, J. Regan and J. Aston. 2001. Social class and higher 
education: Issues affecting decisions on participation by lower social class groups. Research Report No. 267. Department for Education and Employment.

Corver, M. 2005. Young participation in higher education. United Kingdom: Higher Education Funding Council for England.

Council on Higher Education. 2013. A proposal for undergraduate curriculum reform in South Africa: The case for a flexible curriculum structure. Pretoria: Council on Higher Education.

Deller, F. and S. Oldford. 2011. Participation of low-income students in Ontario @ Issue Paper No. 11. Toronto: Higher Education Quality Council of Ontario.

Department of Business, Innovation and Skills. 2012. Widening participation in higher education. https://www.gov.uk/government/policies/widening-participation-in-higher-education-4

De Vellis, F. 2012. Scale development. Theory and applications. $3^{\text {rd }}$ Edition. Thousand Oaks: Sage.

Garces, L. M. 2012. The impact of affirmative action bans in graduate education. The Civil Rights Project, University of California.

Golom, F. D. 2018. Reframing the dominant diversity discourse: Alternate conversations for creating whole system change. Metropolitan Universities 29(1): 11-27.

Guri-Rosenbilt, S., H. Sebkova and U. Teichler. 2007. Massification and diversity of higher education systems: Interplay of complex dimensions. Higher Education Policy 20(4): 373-389.

HEFCE see Higher Education Funding Council for England.

Higher Education Authority 2008. National Plan for Equity of Access to Higher Education 2008 - 2013 (National Office of Equity of Access to Higher Education, Trans.) (pp. 1 -100). Dublin: National Office of Equity of Access to Higher Education, Higher Education Authority.

Higher Education Funding Council for England. 2013. Trends in young participation in higher education, 1-37. United Kingdom: Higher Education Funding Council for England.

Hovdhaugen, E. 2013. Widening participation in Norwegian Higher Education. Leicester: HEFCE.

Jacob, W. J. 2006. Social justice in Chinese higher education: Regional issues of equity and access. Review of Education 52: 149-169.

James, R. 2007. Social equity in a mass, globalised higher education environment: The unresolved issue of widening access to university. http://www.cshe.unimelb.edu.au (Accessed 15 July 2018).

Johnson, R. B. and A. J. Onwuegbuzie. 2004. Mixed methods research: A research paradigm whose time has come. Educational Researcher 33(7): 14-26.

Keane, E. 2011. Dependence-deconstruction: Widening participation and traditional-entry students transitioning from school to higher education in Ireland. Teaching in Higher Education 16(6): 707-718.

Layer, G. (Ed.). 2005. Closing the equity gap: The impact of widening participation strategies in the UK and the USA. Leicester: National Institute of Adult Continuing Education.

Lui, Y. 2013. Meritocracy and the Gaokao: A survey study of higher education selection and socioeconomic participation in East China. British Journal of Sociology of Education 34(5-6): 868887.

Marks, G., N. Fleming, M. Long and J. McMillan. 2000. Patterns of participation in year 12 and higher education in Australia: Trends and issues (Longitudinal Surveys of Australian Youth (LSAY)). Camberwell: Australian Council for Educational Research.

McCowan, T. 2016 Equity of access to higher education. http://www.heart-resources.org/reading pack/equity-access-higher-education/ (Accessed 21 June 2018).

Monyooe, L., M. Tjatji and E. Mosese. 2014. South Africa`s increased matriculation passes: What skunks behind the rose? Journal of Education and Training Studies 2(1): 180-192.

Mouton, N., G. P. Louw and G. Strydom. 2013. Critical challenges of the South African school system. International Business \& Economics Research Journal 12(1): 31-44. 
National Department of Health. 2012. Human Resources for Health South Africa. HRH Strategy for the Health Sector: 2012/13 to 2016/17. http://www.health.gov.za/index.php/2014-03-17-09-0938/strategic-documents/Sub-theme/95-2012s (Accessed 20 December 2017).

Onwuegbuzie, A. J. and N. L. Leech. 2007. A call for qualitative power analysis. Quality and Quantity 41(1): 105-121.

Orton, P. 2015. Access to higher education in the health sciences - A Policy Implementation Analysis. PhD., University of KwaZulu Natal.

Powell, J. J. W. and H. Solga. 2011. Why are higher education participation rates in Germany so low? Institutional barriers to higher education expansion. Journal of Education and Work 24(1-2): 4968.

Power, L., K. Millington and S. Bengtsson. 2015. Capacity building in higher education topic guide. http://www.heart-resources.org/wp-content/uploads/2015/09/Capacity-Building-in-HigherEducation-Topic-Guide.pdf (Accessed 21 June 2018).

Riddell, S. and E. Weedon. 2014. European higher education, the inclusion of students from underrepresented groups and the Bologna Process. International Journal of Lifelong Education 33(1): $26-44$

South Africa. 2013. Department of Higher Education and Training White Paper: Post-School Education and Training. http://www.http://dhet.gov.org (Accessed 20 December 2017).

Statistics South Africa. 2017. Mid-Year population estimates. http://www.statssa.gov.za/ publications/P0302/P03022017.pdf (Accessed 26 March 2018).

Streiner, D. L. and G. R. Norman. 1995. Health measurement scales. A practical guide to their development and use. $2^{\text {nd }}$ Edition. New York: Oxford University Press

Tashakkori, A. and C. Teddlie. (Ed.). 2003. Handbook of mixed methods in social and behavioural research. Thousand Oaks: Sage Publications.

Telles, E. and M. Paixao. 2013. Affirmative action in Brazil. LASAForum XL1V. http://lasa.international.pitt.edu/forum/files (Accessed 2 August 2018).

Van der Merwe, L. J., G. J. van Zyl, A. St Clair Gibson et al. 2016. South African medical schools: Current state of selection criteria and medical students' demographic profile. South African Medical Journal 106(1): 76-81.

Wang, L. 2011. Social exclusion and inequality in higher education in China: A capability perspective. International Journal of Educational Development 31: 277-286.

Wolfenden, K. J. 2013. Race in elite American universities: Diversity as distraction. Student Pulse 5(2): 1/1. http://www.studentpulse.com/articles/726/race-in-elite-american-universities-diversity-asdistraction (Accessed 26 March 2018.) 